\title{
Pedological Characterization of Some Typical Alluvial Soils of Kilombero District, Tanzania
}

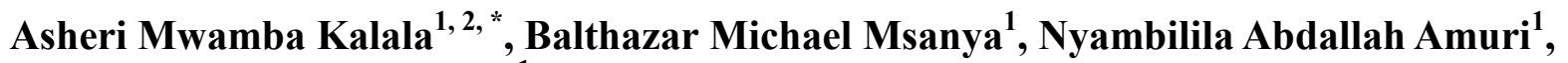 \\ Johnson Mashambo Semoka ${ }^{1}$ \\ ${ }^{1}$ Department of Soil and Geological Sciences, College of Agriculture, Sokoine University of Agriculture, Morogoro, Tanzania \\ ${ }^{2}$ Tumbi Agricultural Research Institute (ARI-Tumbi), Tabora, Tanzania
}

\section{Email address:}

asherikalala@yahoo.com (A. M. Kalala),bmmsanya@gmail.com (B. M. Msanya), semoka@yahoo.com (J. M. Semoka), amurnyambilila@yahoo.com (N. A. Amuri)

${ }^{*}$ Corresponding author

\section{To cite this article:}

Asheri Mwamba Kalala, Balthazar Michael Msanya, Johnson Mashambo Semoka, Nyambilila Abdallah Amuri. Pedological Characterization of Some Typical Alluvial Soils of Kilombero District, Tanzania. American Journal of Agriculture and Forestry. Vol. 5, No. 1, 2017, pp. 1-11. doi: 10.11648/j.ajaf.20170501.11

Received: December 18, 2016; Accepted: January 4, 2017; Published: March 2, 2017

\begin{abstract}
This study was carried out in Kilombero District, Tanzania with the objective of characterizing the soils in terms of their morphology, genesis, physico-chemical properties and classification. Three pedons KISA-P1, MKU-P1 and MBA-P1 were identified within the Kilombero Valley, dug, described and sampled. Disturbed and undisturbed soil samples were taken from designated pedogenic horizons for physical and chemical analysis in the laboratory. Using both field and laboratory data soils were classified using both USDA Soil Taxonomy and World Reference Base for Soil Resources schemes of classification. Results show that the three pedons were developed under Isohyperthemic temperature and Aquic moisture regimes. All pedons were deep $(100-120 \mathrm{~cm})$. Whereas Pedons KISA-P1 and MBA-P1 had sandy clay loam topsoils overlying sandy clay subsoils, Pedon MKU-P1 had clayey texture throughout its profile depth. All pedons had low chromas of $\leq 3$ and redoximorphic features in form of abundant mottles particularly in the subsoils. Topsoils of Pedons KISA-P1 and MBA-P1 had dominantly friable to very friable moist consistence while those of Pedon MKU-P1 had very firm moist consistence. Subsoil moist consistence varied from firm to extremely firm (Pedons KISA-P1 and MKU-P1) and from friable to very firm (Pedon MBA-P1). Structures were dominantly weak to moderate subangular blocky in all studied soils but some horizons were structureless single grained and massive. Soil reaction ranged from extremely acid (topsoil of MBA-P1) to mildly alkaline (subsoil of MKU-P1) with $\mathrm{pH}$ values of 4.44 and 6.73 respectively. Topsoil organic carbon and total nitrogen contents in the studied pedons were low (0.66 to $1.4 \%)$ and very low to low $(0.08$ to $0.19 \%)$ respectively. $\mathrm{CEC}_{\text {soil }}$ values were rated as low to medium ranging from 8.4 to $23.8 \mathrm{cmol}(+) / \mathrm{kg}$ respectively in Pedon KISA-P1 and Pedon MKU-P1. Percent BS values varied between and within studied pedons and ranged from low $<50 \%$ to high $>50 \%$. Studied soils manifested nutrient imbalances in respect of basic cations. On the overall, fertility of the studied soils was rated as low to medium. According to USDA Keys to Soil Taxonomy, Pedons KISA-P1 and MKU-P1 classified as Inceptisols, equivalent to Cambisols in WRB for Soil Resources whereas Pedon MBA-P1 classified as Entisols equivalent to Fluvisols. All three sites were recommended for paddy production.
\end{abstract}

Keywords: Physico-Chemical Properties, USDA Soil Taxonomy, WRB, Pedons, Kilombero District, Tanzania

\section{Introduction}

Pedological characterization is very important in providing valuable information and knowledge on soil characteristics. It gives clear understanding of soil genesis, morphology, classification and spatial distribution of soils in an area $[1,2]$.
There are several soil forming factors, which influence the morphology of a given soil, including climate, parent material, biota, relief and time [1]. The study area Kilombero Valley is located in Ulanga and Kilombero Districts of Morogoro Region, Tanzania. The valley lies at the foot of the Great Escarpment of East Africa and has a total length of $250 \mathrm{~km}$ and a width of up to 
$65 \mathrm{~km}$, covering an area of about $11,600 \mathrm{~km}^{2}[3,4]$. The soils of the valley comprise alluvial materials deposited by floods, which occur during rainy season. Declining soil and crop productivity is a major problem facing smallholder farmers (particularly rice producers) in Kilombero, Tanzania [5, 6] and this is contributed by continuous cropping without addition of adequate external soil fertility inputs $[4,7]$. Recent studies have confirmed that deficiency of some macronutrients like nitrogen, potassium, phosphorus and sulphur is a major problem in many soils of Kilombero Valley $[6,8,9]$. In dealing with the deficiencies, understanding of soil genesis, morphology and other key properties is inevitable to allow sustainable use of the soil resources. Hence thorough knowledge about the soils is essential [10]. Most research works in Kilombero Valley were conducted on the basis of studying topsoils to about $20-30 \mathrm{~cm}$ depth and recommendations were made in respect of topsoil characteristics $[6,8,9]$. Yet, soil fertility specialists engaged in transferring agronomic technologies from one area to another require well characterized data of the entire pedon including the subsoil [2]. With regard to availability of such information in Tanzania, there is a big gap between need for pedological soil characterization and actual work that has already been done [2]. It was reported that only 3\% of Tanzanian soils were mapped and characterized in sufficient detail [10]. The existing national soil-terrain (SOTER) inventory was produced at a scale of 1:2 000000 and this is mostly suitable for planning at national level and not practical for fertilizer and agronomic studies [11]. Efforts have been made by several researchers to map and classify soils in various ecologies in Tanzania [2]. However, not much is known about soils of Kilombero Valley in sufficient detail to allow ranking of their potential for various agricultural and non-agricultural uses and for transferring of technology to other areas with similar ecological conditions in Tanzania. Therefore, this study aimed at characterizing and classifying typical soils of Kilombero Valley according to Keys to Soil
Taxonomy and the WRB for Soil Resources, to provide the needed data for land use planning and for making appropriate agronomic recommendations.

\section{Materials and Methods}

\subsection{Description of the Study Area}

The study was carried out in Kilombero District, Tanzania (Figure 1) with representative soil pedons KISA-P1, MKU$\mathrm{P} 1$ and MBA-P1 in Kisawasawa, Mkula and Mbasa Wards, respectively. The three pedons are developed within the Kilombero Valley, which is a vast floodplain, between the Kilombero River in the south-east and the Udzungwa Mountains in the north-west. The valley is constituted by a series of flat alluvial plains with complex sedimentation pattern, subject to regular flood from braiding rivers originating from the Udzungwa Mountains [12]. The three sites are located in agro-ecological zone E10, within the "Eastern Plateaux and Mountain Blocks" physiographic unit with an area of about $6,253 \mathrm{~km}^{2}$ [13]. Table 1 presents the salient features of the study sites. The soil parent materials of the area are dominantly alluvium derived from metamorphic rocks (mainly gneisses, quartzites and schists) of the Udzungwa Mountains. Whereas rainfall recorded at Kilombero Sugar Estate Weather Station for 20 years (between 1996 and 2015) for the sites at Mkula and Kisawasawa have an average total of $1378 \mathrm{~mm}$ with the peak (308.4 mm) in April (Figure 2). [4] Reported an average total rainfall value of $1200 \mathrm{~mm}$ for Kilombero District. The average minimum and maximum temperatures for 20 years were 20.5 and $31.6^{\circ} \mathrm{C}$, respectively. All pedons have an isohyperthermic soil temperature regime (STR) and aquic soil moisture regime. Altitude across the study sites ranges from about 262 to $302 \mathrm{~m}$ a. s. 1 .

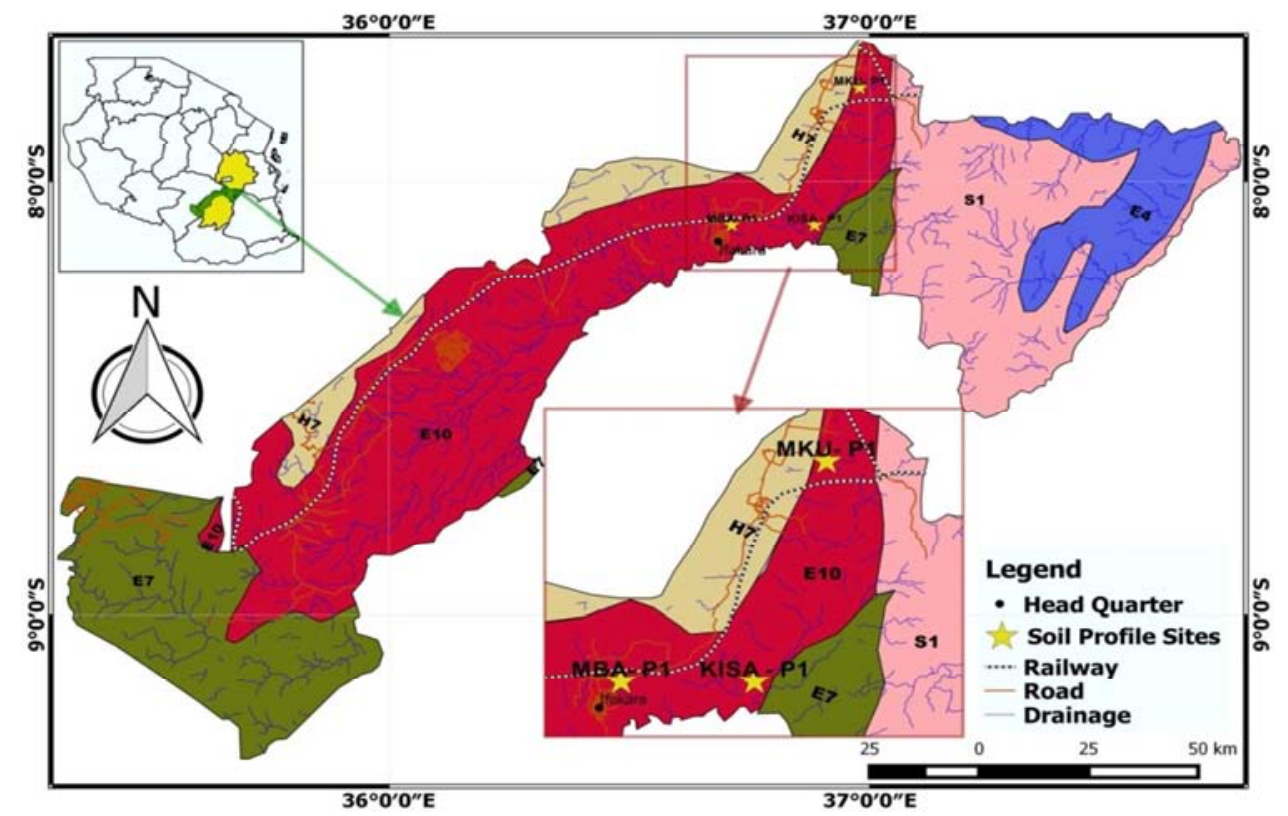

AEZ E10:1400 - 1600 mm rainfall, flat alluvial plains with complex sedimentation pattern, Altitude range 250 - $600 \mathrm{~m}$ a. s. 1.

Figure 1. Kilombero District Map Showing Location of Studied Soil Profiles. 
Table 1. Important characteristics of studied sites in Kilombero District, Tanzania.

\begin{tabular}{|c|c|c|c|c|c|c|c|}
\hline 1) Pedon No. & Coordinates & $\begin{array}{l}\text { Altitude } \\
\text { m asl. }\end{array}$ & ${ }^{2)}$ MAR mm & $\begin{array}{l}\text { Lithology/ parent } \\
\text { materials }\end{array}$ & Land Use & ${ }^{3)}$ STR & ${ }^{4)} \mathrm{SMR}$ \\
\hline KISA-P1 & $036^{\circ} 53^{\prime} 31.6^{\prime \prime}$ E $07^{\circ} 53^{\prime} 56.4^{\prime \prime} \mathrm{S}$ & 293 & 1378 & $\begin{array}{l}\text { Alluvium derived from } \\
\text { metamorphic rocks }\end{array}$ & $\begin{array}{l}\text { Mostly rain-fed } \\
\text { paddy }\end{array}$ & Isohyperthermic & Aquic \\
\hline MKU-P1 & $036^{\circ} 55^{\prime} 08.1^{\prime \prime}$ E $07^{\circ} 47^{\prime} 41.4^{\prime \prime} \mathrm{S}$ & 302 & Same as above & Same as above & Same as above & Same as above & Same as above \\
\hline MBA-P1 & $036^{\circ} 42^{\prime} 42.8^{\prime \prime}$ E $08^{\circ} 05^{\prime} 46.0^{\prime \prime} \mathrm{S}$ & 262 & Same as above & Same as above & Same as above & Same as above & Same as above \\
\hline
\end{tabular}

${ }^{1)}$ Soil pedons: KISA-P1 (Kisawasawa Ward) Pedon MKU- P1 (Mkula Ward) Pedon MBA-P1 (Mbasa Ward)

${ }^{2)}$ MAR: Mean Annual Rainfall for 20 years

3) STR: Soil Temperature Regime

${ }^{4)}$ SMR: Soil Moisture Regime

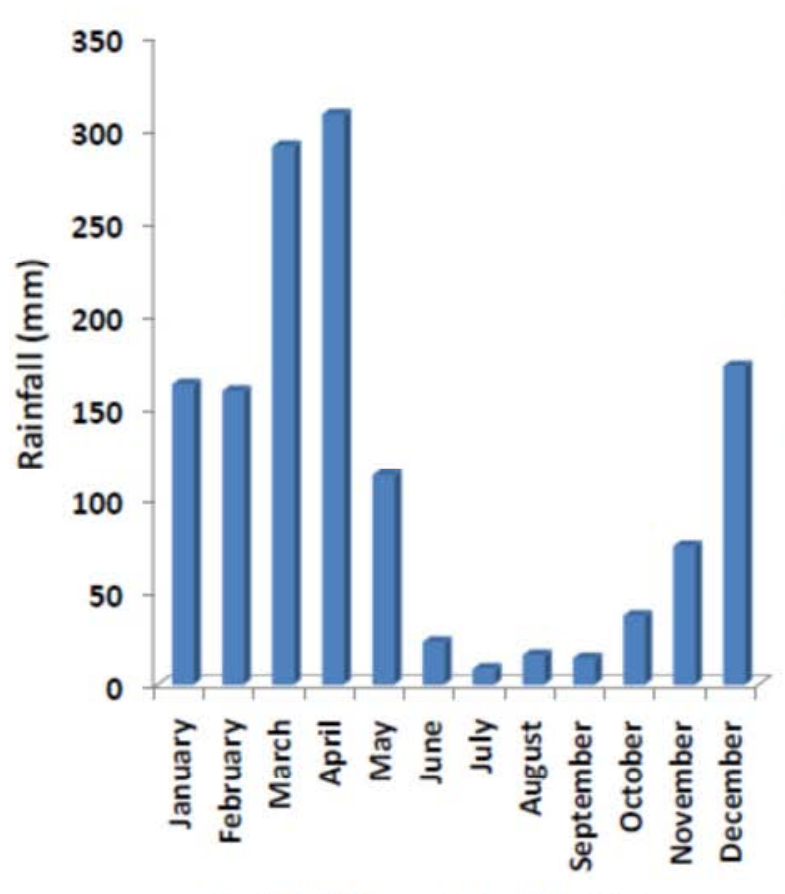

Rainfall Mean Monthly Values 1996- 2015

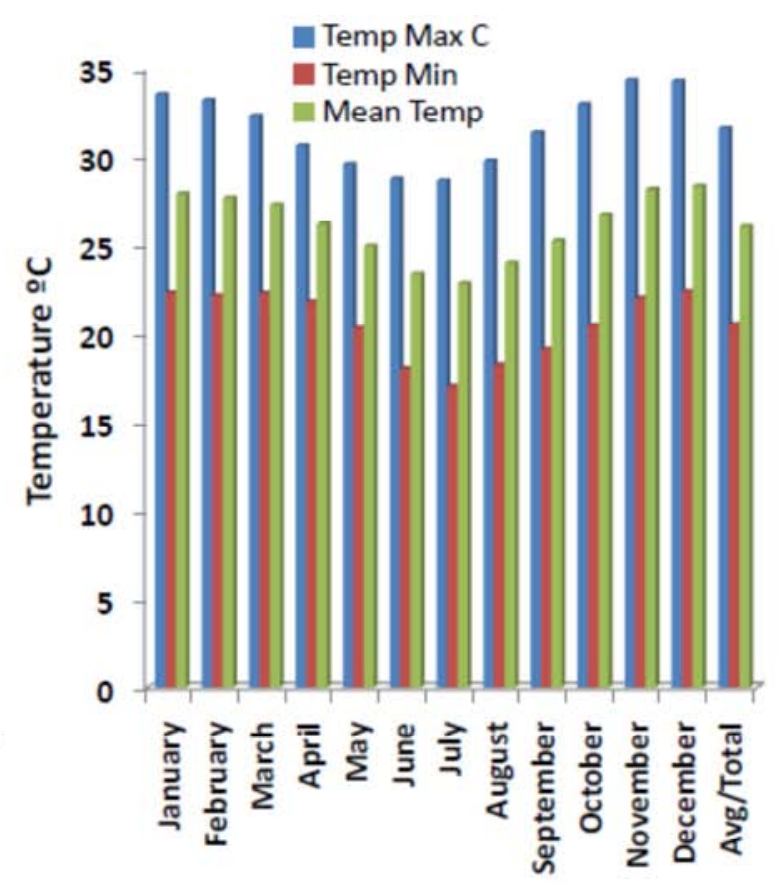

Temperature Mean Monthly Values $1996-2015$

Source: Kilombero Sugar Weather Station

Figure 2. Mean Monthly Rainfall and Temperature for the 20 Years.

\subsection{Field Work}

Reconnaissance field survey was carried out using transect walks, auger observations and descriptions to establish three representative study sites. Three representative soil profiles, one for each site, were identified, excavated and described according to FAO Guidelines for Soil Description [14]. Data on landforms, soil morphological characteristics, elevation, slope gradient, parent material (lithology), vegetation and land use/crops were collected from the three observation sites. The data were filled on field description forms designed based on Guidelines for Soil Description by FAO [14]. Soil profile pits were geo-referenced using Global Positioning System (GPS) Model OREGON 400t. Soil colours were determined by Munsell soil colour charts [15]. In each profile pit, undisturbed (core) soil samples at depths of $0-5 \mathrm{~cm}, 45-50$ $\mathrm{cm}$ and $95-100 \mathrm{~cm}$ ) were taken. Disturbed samples (weighing about $1 \mathrm{~kg}$ ) were taken from each of the designated genetic soil horizons of soil profiles for laboratory physical, chemical and mineralogical analyses.

\subsection{Laboratory Methods}

Undisturbed (core ring) samples were used for determination of bulk density and moisture retention characteristics. Bulk density was determined by the core method [16]. Pressure (plate/pressure) membrane apparatus [11] was used to determined soil water-holding characteristics. Disturbed soil samples were air-dried, ground and passed through a 2-mm sieve for physical and chemical soil properties determination. Particle size distribution was determined by hydrometer method [17] after dispersing soil with sodium hexametaphosphate and textural classes determined using the USDA textural triangle [18]. Soil $\mathrm{pH}$ in water and in $1 \mathrm{M} \mathrm{KCl}$ was measured potentiometrically using a soil:water $/ \mathrm{KCl}$ ratio of 
1:2.5 weight to volume basis [19]. Potentiometric method also was used to determine electrical conductivity. Organic carbon was determined by Walkey-Black wet oxidation method [20] and total nitrogen (TN) was determined by micro-Kjeldahl digestion method [21]. Basic cations (Ca, $\mathrm{Mg}, \mathrm{K}$ and $\mathrm{Na}$ ) extracted by ammonium acetate $\left(\mathrm{NH}_{4} \mathrm{OAc}\right)$ method [22] were determined using atomic absorption spectrophotometer [23]. The total exchangeable bases (TEB) were calculated arithmetically as the sum of the four exchangeable bases $\left(\mathrm{Ca}^{2+}, \mathrm{Mg}^{2+}, \mathrm{K}^{+}\right.$and $\left.\mathrm{Na}^{+}\right)$for a given soil sample. Other parameters including $\mathrm{C} / \mathrm{N}$ ratio, exchangeable sodium percentage (ESP), Chemical Index of Alteration (CIA), Silt clay ratio (SCR) and base saturation percentage (BS \%) were calculated. Determination of multielement oxides for selected soil horizons was done as follows: $200 \mathrm{~g}$ of fine earth soil samples were weighed and open air-dried by using Infrared lamps for two hours. Samples were then ground to particle size $\leq 177 \mu \mathrm{m}(80$ Mesh) using swing mill pulverizer. An AAS machine version 208FS was used to quantify $\mathrm{Mg}$ and $\mathrm{Na}$, while other elemental oxides were measured using PANalytical, Minipal 4 Energy Dispersive X-Ray Fluorescence Spectrometer (ED-XRF) Model PW4030/45B.

\subsection{Classification of Soils}

Using field and laboratory data, soil pedons were classified to family level of USDA Soil Taxonomy [18] and to Tier-2 of World Reference Base (WRB) for Soil Resources [24].

\section{Results and Discussion}

\subsection{Soil Morphology and Genesis of the Studied Soils in Kilombero Valley}

Salient morphological characteristics of the studied profiles are given in Table 2. All studied pedons were deep to very deep and had shallow water tables. Pedons KISA-P1 and MBA-P1 had sandy clay loam topsoils overlying sandy clay subsoils whereas Pedon MKU-P1 had dominantly heavy clay horizons alternating with sandy clay and clay horizons. Topsoil of Pedon KISA-P1 was black while Pedons MKU-P1 and MBA-P1 had respectively grayish brown and very dark grayish brown topsoils. Pedon MKU-P1 had extremely hard dry consistence throughout its depth, being attributed to the heavy clay texture of soil. The other pedons had relatively lower dry consistence but ranging from slightly hard to very hard in Pedon KISA-P1 and from soft to very hard in Pedon MBA-P1. Pedon MBA-P1 was typically structureless single-grained while Pedons KISA-P1 and MKU-P1 had horizons with weak to moderate subangular blocky structure alternating with structureless single grained and structureless massive clods. All the pedons had abundant redoximorphic features in form of strong brown (iron) mottles due to the reducing/waterlogged soil conditions. Researchers $[25,26,27]$ observed similar mottles respectively in subsoils of floodplains in Nigeria and in surface-water grey soils in Bangladesh. Horizon boundary attributes varied among and within pedons, whereby distinctness ranged from abrupt to gradual, but topography was dominantly smooth. On the overall, morphology and genesis of the studied soils were typical of alluvial soil formation.

Table 2. Main morphological features of the studied soil profiles in Kilombero District, Tanzania

\begin{tabular}{|c|c|c|c|c|c|c|c|c|}
\hline Pedon & Horizon & Depth (cm) & ${ }^{1)}$ Texture & ${ }^{2)}$ Moist colour & ${ }^{3)}$ Consistence & ${ }^{4)}$ Structure & ${ }^{5)}$ Mottles & $\begin{array}{l}{ }^{6} \text { Horizon } \\
\text { boundary }\end{array}$ \\
\hline \multirow[t]{5}{*}{ KISA-P1 } & Ap & $0-12$ & SCL & bl(10YR2/1) & sh; fr, \& ss \& sp & $\mathrm{m} ; \mathrm{m} ; \mathrm{cr}$ & - & cs \\
\hline & BA & $12-23$ & SCL & bl(10YR2/1) & vh; fr; ss \& sp & stl-mas & - & as \\
\hline & Bwg1 & $23-45$ & SCL & $\operatorname{vdg}(7.5 \mathrm{YR} 3 / 1)$ & vh; fr; s \& p & stl-mas & f-c; fi; sb; Fe & cs \\
\hline & Bwg21 & $45-74$ & $\mathrm{SC}$ & $\mathrm{g}(7.5 \mathrm{YR} 5 / 1)$ & vh; fi; s \& p & $\mathrm{w} ; \mathrm{c} ; \mathrm{sbk}$ & $\mathrm{f}-\mathrm{c} ; \mathrm{fi} ; \mathrm{sb} ; \mathrm{Fe}$ & gs \\
\hline & Bwg22 & $74-120+$ & $\mathrm{SC}$ & $\mathrm{g}(7.5 \mathrm{YR} 5 / 1)$ & vh; fi; s \& p & $\mathrm{w} ; \mathrm{c}, \mathrm{sbk}$ & $\mathrm{f}-\mathrm{c} ; \mathrm{fi} ; \mathrm{sb} ; \mathrm{Fe}$ & - \\
\hline \multirow[t]{5}{*}{ MKU-P1 } & Apg & $0-14 / 22$ & $\mathrm{hC}$ & $\mathrm{gb}(10 \mathrm{YR} 6 / 1)$ & eh; vfi; s \& p & $\mathrm{m} ; \mathrm{f} \& \mathrm{~m} ; \mathrm{sbk}$ & $\mathrm{f} ; \mathrm{fi} ; \mathrm{rb} ; \mathrm{Fe}$ & aw \\
\hline & $\mathrm{Cg}$ & $11 / 22-29$ & $\mathrm{SC}$ & vdgb(10YR3/2) & eh; vfi; s \& p & stl-sg & $\mathrm{c} ; \mathrm{m} ; \mathrm{br} ; \mathrm{Fe}$ & as \\
\hline & $\mathrm{Abg}$ & $29-43 / 47$ & $\mathrm{hC}$ & $\operatorname{br}(7.5 Y R 2.5 / 1)$ & eh; efi; vs \& vp & $\mathrm{m} ; \mathrm{m} ; \mathrm{ab} \& \mathrm{sbk}$ & $\mathrm{c} ; \mathrm{m} ; \mathrm{bg} ; \mathrm{Fe}$ & as \\
\hline & $\mathrm{ABg}$ & $43 / 47-65 / 83$ & $\mathrm{hC}$ & $\operatorname{vdg}(10 \mathrm{YR} 3 / 1)$ & eh; efi; vs \& vp & w-m; m \& c; sbk & c; vfi $+f i ; y b ; F e$ & aw \\
\hline & Bwg & $65 / 83-116+$ & $\mathrm{C}$ & $\mathrm{yb}(10 \mathrm{YR} 5 / 6)$ & eh; efi; vs \& vp & $\mathrm{m} ; \mathrm{m} ; \mathrm{sbk}$ & $\mathrm{c} ; \mathrm{fi} ;(50 \% \mathrm{yb}+50 \% \mathrm{gb})$ & - \\
\hline \multirow[t]{3}{*}{ MBA-P1 } & Apg & $0-28 / 35$ & SCL & $\operatorname{vdgb}(10 \mathrm{YR} 3 / 2$ & so; vfr; ns \& np & stl-sg & vf; fi; rb; Fe & aw \\
\hline & C11g & $28 / 35-74$ & $\mathrm{SC}$ & br(10YR5/3) & sh; fr; ss \& sp & stl-sg & c; vf; bg; Fe & as \\
\hline & $\mathrm{C} 12 \mathrm{~g}$ & $74-120+$ & $\mathrm{SC}$ & $\mathrm{pb}(10 \mathrm{YR} 6 / 3)$ & vh; vfi; ss \& sp & stl-sg & $\mathrm{c} ; \mathrm{vf} ; \mathrm{bg} ; \mathrm{Fe}$ & - \\
\hline
\end{tabular}

\footnotetext{
1) Texture: $\mathrm{SC}=$ sandy clay; $\mathrm{SCL}=$ sandy clay loam; $\mathrm{C}=$ clay

${ }^{2)}$ Colour: $g=$ gray; gb = grayish brown; vdgb = very dark grayish brown; vdg= very dark gray; bl = black; yb = yellowish brown; br = brown; $\mathrm{pb}=$ pale brown

${ }^{3)}$ Consistence: Dry: so =soft; $\mathrm{sh}=$ slightly hard; $\mathrm{h}=$ hard; vh = very hard; eh =extremely hard. Moist: fr = friable; fi = firm; vfi =very firm; efi = extremely firm. Wet: $\mathrm{ns}=$ non-sticky; $\mathrm{ss}=$ slightly sticky; $\mathrm{vs}=\mathrm{vs} . \mathrm{np}=$ non-plastic; $\mathrm{sp}=$ slightly plastic; $\mathrm{p}=$ plastic; $\mathrm{vp}=\mathrm{very}$ plastic

${ }^{4)}$ Structure: Grade: $\mathrm{m}=$ moderate; $\mathrm{w}=$ weak; = structureless single grained; stl-mas = structureless massive. Size: $\mathrm{f}=$ fine; $\mathrm{m}=\mathrm{medium} ; \mathrm{c}=\mathrm{coarse}$. Type: $\mathrm{cr}=$ crumbs; $a b=$ angular blocky; sbk =subangular blocky; mas = massive

${ }^{5)}$ Mottles: Abundance: $\mathrm{f}=\mathrm{few} ; \mathrm{c}=$ common; $\mathrm{a}=$ abundant. Size: $\mathrm{vf}=$ very fine; $\mathrm{fi}=$ fine; medium. Colour: $\mathrm{sb}=\mathrm{strong}$ brown; $\mathrm{bg}=\mathrm{bluish}$ gray; $\mathrm{yb}=\mathrm{yellowish}$ brown. Type: $\mathrm{Fe}=$ iron

${ }^{6)}$ Horizon boundary: Distinctness: $\mathrm{a}=$ abrupt; $\mathrm{c}=$ clear; $\mathrm{g}=$ gradual. Topography: $\mathrm{s}=$ smooth; $\mathrm{w}=$ wavy.
} 


\subsection{Physical Properties of the Studied Soils in Kilombero Valley}

\subsubsection{Soil Moisture Retention Characteristics}

Figure 3 presents results on soil moisture characteristics of two of the studied pedons. The soil moisture release curves clearly indicate that Pedon MKU-P1 held more moisture than Pedon MBA-P1 at any suction level for all the three pedon sections. Moreover, Pedon MKU-P1 released soil moisture more gradually with increasing pressure than Pedon MBA$\mathrm{P} 1$. The difference in behaviour of the two pedons was attributed to the fine texture of the former pedon vis-à-vis the relatively coarser texture of the latter. The results on volumetric moisture content complied with the heavy clayey texture in Pedon MKU-P1 as opposed to dominance of sand particles in Pedon MBA-P1 (Table 2). [28] reported a pedon with high clay content to have higher moisture retention capacity with a gradual moisture decrease as suction potential increased, compared to one dominated by sand with a rapid decrease in moisture content as the suction potential increased. This phenomenon suggests an effect of drastic dryness of field crops whenever there is a dry spell during the rainy season in the case of Pedon MBA-P1 $(28,29)$. Average rainfall data (Figure 2) show December to May rainfall is above $100 \mathrm{~mm} /$ month allowing farmers to practice both rainfed and irrigated rice production in the district.
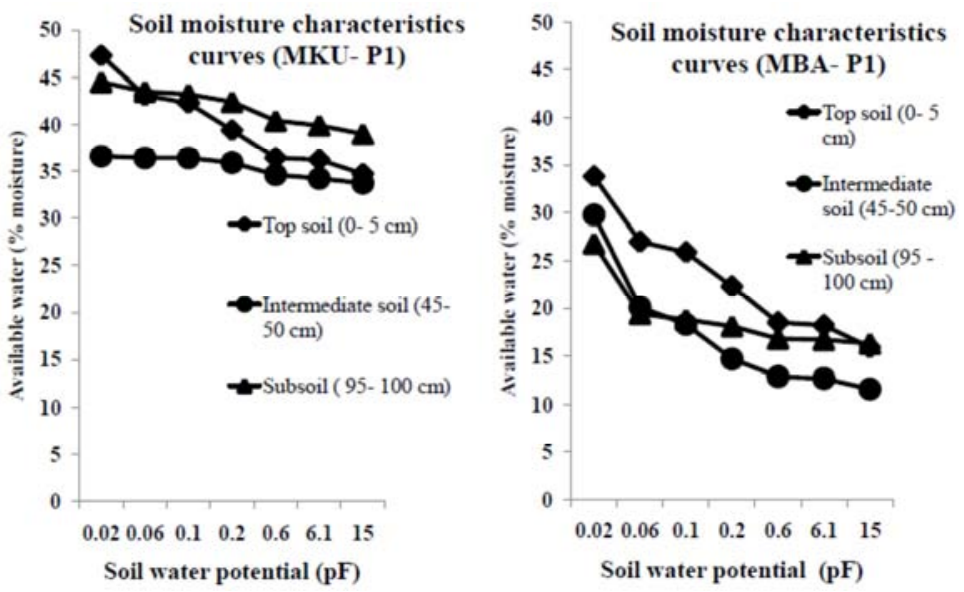

Figure 3. Soil moisture characteristic curves for Mkula and Mbasa Sites, Kilombero District, Tanzania.

\subsubsection{Texture, Silt/Clay Ratio, Bulk Density and Porosity}

Table 3 presents data on other soil physical properties including texture, silt/clay ratio, bulk density and porosity of the soils. Pedons KISA-P1 and MBA-P1 had sandy clay loam topsoils overlying sandy clay subsoils while Pedon MKU-P1 had sandy clay to clay topsoil overlying clay subsoils. Pedon MKU-P1 had much heavier texture throughout profile depth when compared with the other two pedons, implying it would behave differently from these two in terms of physical and chemical properties. For example, clayey texture is associated with high water retention capacity and high nutrient supply [25]. Pedon MKU-P1 would offer more favourable conditions for paddy than the other two pedons. Clay content increased somewhat with depth in all pedons providing some indication of clay eluviation-illuviation, although there was no clear evidence of clay illuviation features (clay cutans) in the subsoils. Some researchers [27, 28] observed consistent clay increase with depth as an indication of clay migration in studies done in Bangladesh and Western-Kenya.

Table 3. Some physical properties of the studied soil profiles of Kilombero District, Tanzania.

\begin{tabular}{|c|c|c|c|c|c|c|c|c|c|c|}
\hline Pedon No. & Horizons & Depth (cm) & Sand & $\begin{array}{l}\text { Clay } \\
\%\end{array}$ & Silt & Textural class & Silt / clay ratio & BD $\mathrm{Mg} / \mathrm{m}^{3}$ & Porosity \% & $\begin{array}{l}\text { Penetration } \\
\text { resistance } \mathrm{kg} / \mathrm{cm}^{2}\end{array}$ \\
\hline \multirow[t]{5}{*}{ KISA-P1 } & Ap & $0-12$ & 62 & 32 & 6 & SCL & 0.19 & nd & nd & nd \\
\hline & $\mathrm{BA}$ & $12-23$ & 62 & 30 & 8 & SCL & 0.27 & nd & nd & nd \\
\hline & Bwg1 & $23-45$ & 58 & 34 & 8 & SCL & 0.24 & nd & nd & nd \\
\hline & Bwg21 & $45-74$ & 54 & 40 & 6 & $\mathrm{SC}$ & 0.15 & nd & nd & nd \\
\hline & Bwg22 & $74-120+$ & 50 & 44 & 6 & $\mathrm{SC}$ & 0.12 & nd & nd & nd \\
\hline \multirow[t]{5}{*}{ MKU-P1 } & Ap & $0-14 / 22$ & 54 & 43 & 3 & $\mathrm{C}$ & 0.07 & 1.15 & 53.5 & 2.3 \\
\hline & $\mathrm{Cg}$ & $11 / 22-29$ & 53 & 42 & 5 & $\mathrm{SC}$ & 0.12 & nd & nd & nd \\
\hline & $\mathrm{Ab}$ & $29-43 / 47$ & 33 & 64 & 3 & $\mathrm{C}$ & 0.05 & 1.64 & 37.3 & 16.5 \\
\hline & $\mathrm{AB}$ & $43 / 47-65 / 83$ & 37 & 58 & 5 & $\mathrm{C}$ & 0.09 & nd & nd & nd \\
\hline & $\mathrm{Bw}$ & $65 / 83-116+$ & 41 & 56 & 3 & $\mathrm{C}$ & 0.05 & 1.47 & 45.6 & 6.6 \\
\hline \multirow[t]{3}{*}{ MBA-P1 } & Apg & $0-28 / 35$ & 71 & 27 & 2 & SCL & 0.03 & 1.54 & 38.1 & 1.83 \\
\hline & C11g & $28 / 35-74$ & 51 & 48 & 1 & $\mathrm{SC}$ & 0.02 & 1.59 & 36.0 & 17.2 \\
\hline & $\mathrm{C} 12 \mathrm{~g}$ & $74-120+$ & 45 & 52 & 3 & $\mathrm{SC}$ & 0.07 & 1.67 & 33.7 & 14.5 \\
\hline
\end{tabular}

nd $=$ not determined $\mathrm{BD}=$ bulk density 
Silt/clay ratio, an indicator of soil susceptibility to detachment and transport, was less than the threshold of 0.4 [30], implying moderate resistance to erosion. Silt/clay ratios in the three pedons showed irregular patterns and were lower in Pedons MKU-P1 and MBA-P1 than in Pedon KISA-P1. The pedons differed in bulk density, whereby Pedon MKU-P1 had a BD of $1.15 \mathrm{Mg} / \mathrm{m}^{3}$ while pedon MBA-P1 had BD of $1.5 \mathrm{Mg} / \mathrm{m}^{3}$ in topsoils. Bulk density affects infiltration, rooting depth, available water capacity, soil porosity, plant nutrient availability, and soil microbial activity, which influence key soil processes and productivity [1, 31, 32]. Bulk density normally increases with soil depth since subsurface layers are more compacted and have less organic matter, aggregation, and root penetration compared to surface layers, hence less pore space [1]. Among other factors, tillage practices done prior to planting temporarily decrease bulk density on the surface but increases at the depth of tillage [32]. Several researchers have observed similar trends of bulk density increasing with depth $[26,33]$ in rice fields. BD values $>$ $1.65 \mathrm{Mg} / \mathrm{m}^{3}$ are unfavorable to root growth in sandy clay loams and clay loams [32]. Thus, the observed BD values in Pedons MKU-P1 and MBA-P1 are favorable in that regard. Table 3 also presents the penetration resistance of the studied pedons. Topsoil penetration resistance values of the pedons ranged from $1.83-2.3 \mathrm{~kg} / \mathrm{cm}^{2}$ while those of subsoils ranged from $6.6-17.2 \mathrm{~kg} / \mathrm{cm}^{2}$. This indicates lower soil compaction in topsoils than in subsoils, which corresponds to the observed low BD values in topsoils. The penetration resistance increased with increasing depth signaling the presence of reduced water movement and creation of water table. Some researchers [28, 29, 30] observed similar trend of low penetration resistance in topsoils than in subsoils. According to [28], penetration resistance of $<30 \mathrm{~kg} / \mathrm{cm}^{2}$ infers a compaction that cannot impair growth and development of crops in the studied profiles.

\subsection{Chemical Properties of the Studied Pedons in Kilombero Valley}

\subsubsection{Soil Reaction (PH), Organic C, Total N, Organic Matter (OM) and C/N Ratio}

Some chemical properties of the studied pedons are presented in Table 4. Soil $\mathrm{pH}$ is the most important chemical characteristic of soil solution. $\mathrm{pH}_{\mathrm{H} 2 \mathrm{O}}$ levels in topsoils of the three pedons ranged between 4.44 and 5.78 (very low to medium), whereas in subsoils they ranged between 5.71 and 6.73 (medium). [31] rated $\mathrm{pH}_{\mathrm{H} 2 \mathrm{O}}$ values of $4.6-4.9$ as very low, $<5.5$ as low and 5.5 to 7.0 as medium. The low $\mathrm{pH}$ in topsoils may be attributed to low amounts of bases caused by leaching during fluctuations of water table and percolation of water during flooding periods, removal of bases through crop harvests and farming practices. [27] Observed similar trend of $\mathrm{pH}$ increasing with depth in annually flooded soils of Bangladesh. Likewise, [34] reported a similar trend of soil $\mathrm{pH}$ increasing with depth in paddy soils of Kilombero Valley. Electrical conductivity (EC) is a measure of relative salt concentration or salinity, and too much salt in the soil can interfere with root function and nutrient uptake $[35,36]$. EC values ranged between 0.01 and $0.05(\mathrm{dS} / \mathrm{m})$ in all pedon horizons implying that all the soils were non-saline. According to $[30,36]$, the topsoil organic carbon (OC) and total nitrogen $(\mathrm{TN})$ contents of the studied soils were low (ranging from 0.66 to $1.4 \% \mathrm{OC}$ ) and very low to low (TN ranging from 0.08 to $0.19 \%$ ). The low values of $\mathrm{OC}$ and $\mathrm{TN}$ may be attributed to burning of crop residues, which decreases the amount of organic matter in the surface soil [4]. The $\mathrm{C} / \mathrm{N}$ ratios of topsoils ranged between 2.95 in MKU-P1 to 12.75 at MBA-P1. Although $\mathrm{OC}$ and $\mathrm{TN}$ decreased with depth as expected, $\mathrm{C} / \mathrm{N}$ ratios did not show a consistent pattern. According to $[31,36], \mathrm{C}: \mathrm{N}$ ratio of 10:1 indicates good quality organic material, although they cautioned that $\mathrm{C}$ : $\mathrm{N}$ ratio might not be a good indicator of soil fertility, and thus encouraged use of individual $\mathrm{C}$ and $\mathrm{N}$ values instead.

Table 4. Some chemical properties of the studied soil profiles of Kilombero District, Tanzania.

\begin{tabular}{|c|c|c|c|c|c|c|c|c|}
\hline \multirow{2}{*}{ Pedon No. } & \multirow{2}{*}{ Horizon } & \multirow{2}{*}{ Depth (cm) } & \multicolumn{2}{|l|}{ pH } & \multirow{2}{*}{$\mathrm{EC}(\mathrm{dS} / \mathrm{m})$} & \multirow{2}{*}{$\begin{array}{l}\text { OC } \\
\% \\
\end{array}$} & \multirow[t]{2}{*}{ TN } & \multirow{2}{*}{ C/N Ratio } \\
\hline & & & $\mathrm{H}_{2} \mathrm{O}$ & $\mathrm{KCl}$ & & & & \\
\hline \multirow[t]{5}{*}{ KISA-P1 } & Ap & $0-12$ & 5.78 & 4.38 & 0.04 & 1.40 & 0.13 & 10.77 \\
\hline & BA & $12-23$ & 6.24 & 4.58 & 0.03 & 0.80 & 0.02 & 40.00 \\
\hline & Bwg1 & $23-45$ & 6.32 & 4.83 & 0.03 & 0.60 & 0.04 & 15.00 \\
\hline & Bwg21 & $45-74$ & 6.34 & 5.36 & 0.05 & 0.31 & 0.03 & 10.33 \\
\hline & Bwg22 & $74-120+$ & 6.54 & 5.58 & 0.05 & 0.19 & 0.04 & 4.75 \\
\hline \multirow[t]{4}{*}{ MKU-P1 } & Ap & $0-14 / 22$ & 5.60 & 4.2 & 0.03 & 0.66 & 0.19 & 2.95 \\
\hline & $\mathrm{Ab}$ & $29-43 / 47$ & 6.37 & 4.83 & 0.01 & 0.42 & 0.07 & 6.00 \\
\hline & $\mathrm{AB}$ & $43 / 47-65 / 83$ & 6.04 & 5.00 & 0.03 & 0.42 & 0.11 & 3.18 \\
\hline & $\mathrm{Bw}$ & $65 / 83-116+$ & 6.73 & 5.18 & 0.03 & 0.29 & 0.08 & 28.9 \\
\hline \multirow[t]{3}{*}{ MBA-P1 } & Apg & $0-28 / 35$ & 4.44 & 4.15 & 0.01 & 1.02 & 0.08 & 12.75 \\
\hline & C11g & $28 / 35-74$ & 5.71 & 4.44 & 0.01 & 1.78 & 0.15 & 11.87 \\
\hline & $\mathrm{C} 12 \mathrm{~g}$ & $74-120+$ & 6.35 & 4.60 & 0.01 & 1.00 & 0.09 & 11.11 \\
\hline
\end{tabular}

\subsubsection{Exchangeable Cations and Related Properties}

Table 5 presents data on exchangeable cations and related parameters of the studied soils. Exchangeable $\mathrm{K}$ ranged between 0.11 and $0.24 \mathrm{cmol}(+) / \mathrm{kg}$ in topsoils. According to [36], K levels are rated as low $(<0.2 \mathrm{cmol}(+) / \mathrm{kg})$ and as 
medium $(0.2$ to $0.4 \mathrm{cmol}(+) / \mathrm{kg})$. Hence Pedon KISA-P1 had medium $\mathrm{K}$ while Pedons MKU-P1 and MBA-P1 had low levels of $\mathrm{K}$. Exchangeable $\mathrm{K}$ critical level for rice was established by [9] as $0.2 \mathrm{cmol}(+) / \mathrm{kg}$, below which rice response to $\mathrm{K}$ application is observed. The soils of MBA- P1 might need application of $\mathrm{K}$ at a recommended rate. The subsoils of the studied pedons had relatively high values of $\mathrm{K}$ indicating leaching of the nutrient from topsoils. Exchangeable $\mathrm{Mg}$ levels ranged between 0.73 and $3.96 \mathrm{cmol}$ $(+) / \mathrm{kg}$ and were rated as low to medium. Like for $\mathrm{K}$, the values of $\mathrm{Mg}$ were higher in the underlying horizons showing there might have been leaching of the nutrient to the subsoil.

Table 5. Exchangeable cations and allied properties of the studied pedons of Kilombero District, Tanzania.

\begin{tabular}{|c|c|c|c|c|c|c|c|c|c|c|c|}
\hline \multirow{3}{*}{ Pedon No. } & \multirow{3}{*}{ Horizons } & \multirow{3}{*}{ Depth (cm) } & \multirow{2}{*}{\multicolumn{4}{|c|}{$\begin{array}{l}\text { Exchangeable bases } \\
\mathrm{cmol}(+) / \mathbf{k g}\end{array}$}} & $\mathrm{CEC}_{\text {soil }}$ & TEB & CEC $_{\text {clay }}$ & \multirow{3}{*}{ BS \% } & \multirow{3}{*}{ ESP } \\
\hline & & & & & & & & & & & \\
\hline & & & $\mathbf{K}$ & Mg & $\mathbf{C a}$ & $\mathbf{N a}$ & & & & & \\
\hline \multirow[t]{5}{*}{ KISA-P1 } & Ap & $0-12$ & 0.25 & 0.73 & 2.15 & 0.24 & 8.4 & 3.37 & 26.3 & 40.1 & 0.9 \\
\hline & BA & $12-23$ & 0.07 & 1.80 & 6.27 & 0.25 & 10.6 & 8.39 & 35.3 & 79.2 & 0.7 \\
\hline & Bwg1 & $23-45$ & 0.07 & 1.92 & 5.86 & 0.30 & 11.0 & 8.15 & 32.4 & 74.1 & 0.9 \\
\hline & Bwg21 & $45-74$ & 0.05 & 0.66 & 2.56 & 0.21 & 8.8 & 3.48 & 22.0 & 39.6 & 1.0 \\
\hline & Bwg22 & $74-120+$ & 0.11 & 1.97 & 5.45 & 0.36 & 10.4 & 7.89 & 23.6 & 75.9 & 1.5 \\
\hline \multirow{4}{*}{ MKU-P1 } & $\mathrm{Cg}$ & $11 / 22-29$ & 0.24 & 7.90 & 6.45 & 0.07 & 23.8 & 14.66 & 56.7 & 61.2 & 0.1 \\
\hline & $\mathrm{Ab}$ & $29-43 / 47$ & 0.12 & 6.42 & 2.36 & 0.09 & 20.0 & 8.99 & 31.3 & 44.9 & 0.3 \\
\hline & $\mathrm{AB}$ & $43 / 47-65 / 83$ & 0.11 & 2.23 & 2.25 & 0.04 & 13.2 & 4.63 & 22.8 & 34.8 & 0.2 \\
\hline & $\mathrm{Bw}$ & $65 / 83-116+$ & 0.11 & 3.29 & 1.16 & 0.09 & 12.0 & 4.65 & 21.4 & 38.5 & 0.4 \\
\hline \multirow[t]{3}{*}{ MBA-P1 } & Apg & $0-28 / 35$ & 0.11 & 2.19 & 1.85 & 0.05 & 12.4 & 4.20 & 45.9 & 33.8 & 0.1 \\
\hline & C11g & $28 / 35-74$ & 0.18 & 6.01 & 3.46 & 0.18 & 17.6 & 9.83 & 36.7 & 55.8 & 0.5 \\
\hline & $\mathrm{C} 12 \mathrm{~g}$ & $74-120+$ & 0.12 & 6.42 & 0.16 & 0.10 & 10.6 & 6.80 & 20.4 & 63.7 & 0.5 \\
\hline
\end{tabular}

Exchangeable Ca levels varied irregularly with depth and ranged between 1.85 and $5.56 \mathrm{cmol}(+) / \mathrm{kg}$ in the topsoils of all pedons. According to [36] topsoil exchangeable Ca levels in Pedon MBA-P1 with loamy texture were rated as low to medium while in Pedons MKU-P1 and KISA-P1 with clayey texture, were rated as medium to high. Sodium levels ranged between 0.04 and $0.30 \mathrm{cmol}(+) / \mathrm{kg}$ in all the three pedons and were rated as very low to low [36]. The values of $\mathrm{Na}$ in the studied pedons were less than $1 \mathrm{cmol}(+) / \mathrm{kg}$ which is the highest level for sodium to be detrimental to plant roots [30]. Exchangeable sodium percentage (ESP) ranged from 0.1 to $1.5 \%$ in all horizons of the studied pedons, hence the soils can be said to be non-sodic as the ESP values are $<6[30$, 36]. The cation exchange capacity (CEC) in topsoils ranged from 8.4 in Pedon KISA-P1 to $18.0 \mathrm{cmol}(+) / \mathrm{kg}$ in Pedon MKU-P1. [30] Categorized CEC of $<5$ as very low, 5-15 as low and $15-25 \mathrm{cmol}(+) / \mathrm{kg}$ as medium. These values suggest that CEC in Pedons KISA-P1 and MBA-P1 was low while it was medium in Pedon MKU-P1. Percent base saturation (BS) varied within and among pedons with no clear trend but with relatively higher topsoil values in Pedons KISA-P1 and MKU-P1 than in Pedon MBA-P1. [36] suggested that soils with $\mathrm{BS}>50 \%$ are fertile soils and vice versa although the following classes were recognized: BS < $20 \%$ as low, $20-60$ as medium, and above $60 \%$ as high.

\subsubsection{Nutrient Balance}

The availability of nutrients for plant uptake does not depend only on their absolute levels in soils but it also depends on nutrient balance. In most cases, the good trend is with calcium higher than magnesium, and magnesium higher than potassium [35]. The exchangeable cations in the study areas followed almost that trend: $\mathrm{Ca}>\mathrm{Mg}>\mathrm{K}>\mathrm{Na}$ at MKU-P1 and KISA-P1. A similar trend was observed in soils of other parts of Tanzania [10, 37, 38, 39]. The pedon MBA-P1 had high $\mathrm{Mg}$ and followed a trend $\mathrm{Mg}>\mathrm{Ca}>\mathrm{K}>\mathrm{Na}$. Other than the absolute amount, the cations availability to plants is sometimes influenced by several ratios including $\mathrm{Ca}: \mathrm{Mg}$, $\mathrm{Mg}: \mathrm{K}$ and $\mathrm{K}$ :TEB (where TEB is total exchangeable bases). The $\mathrm{Ca}$ /TEB ratios in the topsoil for studied pedons ranged from 0.44 to 0.64 (Table 6) and decreased down the profile. According to [30] $\mathrm{Ca} / \mathrm{TEB}$ ratios of more than 0.5 may affect the uptake of other bases, particularly $\mathrm{Mg}$ and/or $\mathrm{K}$, as calcium induced deficiency of $\mathrm{Mg}$ and/or $\mathrm{K}$ may become visible. Thus, Ca may influence uptake and induce deficiency of $\mathrm{K}$ at Kisawasawa (KISA-P1) and Mkula (MKU- P1). The $\mathrm{Ca} / \mathrm{TEB}$ at Mbasa (MBA-P1) was almost optimal. $\mathrm{Ca} / \mathrm{Mg}$ ratios ranged from 0.84 to 2.95 generally decreasing with depth in all the pedons showing that $\mathrm{Ca}$ content was higher in topsoils than in subsoils.

Table 6. Nutrient ratios in the studied pedons of Kilombero District, Tanzania.

\begin{tabular}{|c|c|c|c|c|c|c|}
\hline \multirow{2}{*}{ Pedon No. } & \multirow{2}{*}{ Horizons } & \multirow{2}{*}{ Depth (cm) } & \multicolumn{3}{|c|}{ Ratios of Nutrients } & \multirow{2}{*}{$\%($ K/TEB $)$} \\
\hline & & & Ca/TEB & $\mathrm{Ca} / \mathrm{Mg}$ & $\mathrm{Mg} / \mathrm{K}$ & \\
\hline \multirow{5}{*}{ KISA-P1 } & Ap & $0-12$ & 0.64 & 2.95 & 2.92 & 7.42 \\
\hline & BA & $12-23$ & 0.75 & 3.48 & 25.71 & 0.83 \\
\hline & Bwg1 & $23-45$ & 0.72 & 3.05 & 27.43 & 0.86 \\
\hline & Bwg21 & $45-74$ & 0.74 & 3.88 & 13.20 & 1.44 \\
\hline & Bwg22 & $74-120+$ & 0.69 & 2.77 & 17.91 & 1.39 \\
\hline \multirow[t]{2}{*}{ MKU-P1 } & Ap & $0-14 / 22$ & 0.57 & 1.40 & 24.75 & 1.64 \\
\hline & $\mathrm{Cg}$ & $11 / 22-29$ & 0.44 & 0.82 & 32.92 & 1.65 \\
\hline
\end{tabular}




\begin{tabular}{|c|c|c|c|c|c|c|}
\hline \multirow{2}{*}{ Pedon No. } & \multirow{2}{*}{ Horizons } & \multirow{2}{*}{ Depth (cm) } & \multicolumn{3}{|c|}{ Ratios of Nutrients } & \multirow{2}{*}{$\%(\mathrm{~K} / \mathrm{TEB})$} \\
\hline & & & $\mathrm{Ca} / \mathrm{TEB}$ & $\mathrm{Ca} / \mathrm{Mg}$ & $\mathrm{Mg} / \mathrm{K}$ & \\
\hline \multirow{6}{*}{ MBA-P1 } & $\mathrm{Ab}$ & $29-43 / 47$ & 0.26 & 0.37 & 53.50 & 1.33 \\
\hline & $\mathrm{AB}$ & $43 / 47-65 / 83$ & 0.49 & 1.01 & 20.27 & 2.39 \\
\hline & $\mathrm{Bw}$ & $65 / 83-116+$ & 0.25 & 0.35 & 29.91 & 2.38 \\
\hline & Apg & $0-28 / 35$ & 0.44 & 0.84 & 20.86 & 2.51 \\
\hline & C11g & $28 / 35-74$ & 0.35 & 0.58 & 33.39 & 1.83 \\
\hline & $\mathrm{C} 12 \mathrm{~g}$ & $74-120+$ & 0.02 & 0.02 & 53.50 & 1.78 \\
\hline
\end{tabular}

[30] Ranked $\mathrm{Ca} / \mathrm{Mg}$ range between 2 and 4 as optimal indicating all studied pedons to have optimal $\mathrm{Ca} / \mathrm{Mg}$ ratios. Topsoils of pedons had $\mathrm{Mg} / \mathrm{K}$ ratios of 2.95 to 24.8 and showed irregular pattern whereby pedon KISA-P1 had an optimal ratio falling between the recommended 1 and 4 for optimal nutrient uptake by plants [30]. In general, there was imbalance between $\mathrm{Mg}$ and $\mathrm{K}$ indicating $\mathrm{Mg}$ was relatively high and would influence negatively uptake of $\mathrm{K}$ by plants. The percentage K/TEB ratios ranged between 1.64 to $7.2 \%$ and decreased down the profile. For MKU-P1, the ratio was low but in Pedons KISA-P1 and MBA-P1 they were above $2 \%$ (Table 5), which is considered favorable for most tropical crops [30].

\subsubsection{Total Elemental Composition}

The total elemental oxides of topsoils and subsoils of studied pedons are presented in Table 7 . The most abundant oxide was $\mathrm{SiO}_{2}$, which ranged from 51.8 to $77.1 \%$ in topsoils, and from 44.4 to $71.1 \%$ in subsoils. The high $\mathrm{SiO}_{2}$ content is an indication of existence of amorphous silica. Contents of $\mathrm{Al}_{2} \mathrm{O}_{3}$ ranged between 0.0 and $14.0 \%$ in topsoils and from 11.5 to 17.5 in subsoils. The contents of topsoil $\mathrm{Fe}_{2} \mathrm{O}_{3}$ ranged between 4.69 and $24.92 \%$ and from 5.37 to $30.61 \%$ in subsoils. The $\mathrm{K}_{2} \mathrm{O}$ contents ranged between 2.77 to 11.5 in topsoils and between 2.61 to 3.25 in subsoils. The total $\mathrm{K}_{2} \mathrm{O}$ in Pedon MBA-P1 was low in topsoil and high in subsoils. This may be attributed to the coarse texture of the soil and hence easy leaching of the element. The other elemental oxides $\mathrm{MnO}, \mathrm{Na}_{2} \mathrm{O}, \mathrm{CaO}, \mathrm{MgO}$ and $\mathrm{TiO}_{2}$ of the studied pedons were in low concentrations (below 3.0\%). According to [39], low levels of these element oxides in the studied soils are associated with leaching during weathering process and due to low concentrations of these elements in parent rocks/minerals.

Table 7. Total elemental composition of the studied soil pedons of Kilombero Valley, Tanzania.

\begin{tabular}{|c|c|c|c|c|c|c|c|c|c|c|c|c|c|}
\hline \multirow{2}{*}{ Pedon } & \multirow{2}{*}{$\begin{array}{l}\text { Pedon } \\
\text { section }\end{array}$} & \multicolumn{12}{|c|}{ Percentage } \\
\hline & & $\mathrm{SiO}_{2}$ & $\mathrm{Al}_{2} \mathrm{O}_{3}$ & $\mathrm{Fe}_{2} \mathrm{O}_{3}$ & $\mathrm{~K}_{2} \mathrm{O}$ & $\mathrm{CaO}$ & $\mathrm{TiO}_{2}$ & MnO & MgO & $\mathrm{Na}_{2} \mathrm{O}$ & $\mathrm{CuO}$ & Total & CIA \\
\hline \multirow[t]{2}{*}{ KISA-P1 } & Topsoil & 77.40 & 0.00 & 4.69 & 11.5 & 1.54 & 2.10 & 0.11 & 0.003 & 0.008 & 0.090 & 97.44 & 0.0 \\
\hline & Subsoil & 50.45 & 17.50 & 21.43 & 3.25 & 2.11 & 2.84 & 0.11 & 0.010 & 0.010 & 0.120 & 97.83 & 76.5 \\
\hline \multirow[t]{2}{*}{ MKU-P1 } & Topsoil & 51.80 & 14.00 & 24.92 & 2.77 & 2.90 & 2.10 & 0.14 & 0.043 & 0.008 & 0.130 & 98.81 & 71.1 \\
\hline & Subsoil & 44.35 & 15.50 & 30.61 & 2.61 & 2.51 & 2.51 & 0.21 & 0.027 & 0.006 & 0.125 & 98.45 & 75.2 \\
\hline \multirow[t]{2}{*}{ MBA-P1 } & Topsoil & 51.80 & 14.00 & 24.92 & 2.77 & 2.90 & 2.10 & 0.14 & 0.043 & 0.008 & 0.130 & 98.81 & 71.1 \\
\hline & Subsoil & 71.10 & 11.50 & 5.37 & 7.61 & 1.05 & 1.39 & 0.04 & 0.003 & 0.001 & 0.080 & 98.14 & 57.1 \\
\hline
\end{tabular}

The current study also involved determination of weathering index referred to "Chemical Index of Alteration" (CIA) using the total elemental composition data to estimate the degree of weathering of studied pedons. The CIA is used and reported by some researchers $[2,40,41]$ as a quantitative indicator of degree of weathering of silicates since feldspars are said to be the most abundant reactive minerals in the earth's crust and that calcium, sodium and potassium are removed from feldspars during weathering process. The authors hypothesized that during weathering, proportion of alumina to alkalis would typically increase in the weathered product and that a good measure of degree of weathering could be obtained by the "Chemical Index of Alteration", defined as:

$\mathrm{CIA}=\left\{\mathrm{Al}_{2} \mathrm{O}_{3} /\left(\mathrm{Al}_{2} \mathrm{O}_{3}+\mathrm{K}_{2} \mathrm{O}+\mathrm{Na}_{2} \mathrm{O}+\mathrm{CaO}\right)\right\} * 100$.

On the basis of subsoil CIA values the studied soils are young in terms of pedogenic development with weathering indices of 76.5, 75.2 and 57.1\% for Pedons KISA-P1, MKUP1 and MBA-P1 respectively. According to [41] the trend shown here suggests that degree of weathering of the soils followed the trend Pedon KISA-P1>Pedon MKU-P1>Pedon MBA-P1. The smaller the CIA value, the younger the soils are in terms of degree of weathering and age of formation [30]. In practical terms, Pedons KISA-P1 and MKU-P1 can be said to display almost the same degree of weathering as their CIA values were almost the same. Pedon MBA-P1 with the smallest CIA value was the least weathered something that may be attributed to more frequent deposition of fresh materials to the site and/or nature and degree of weathering of the transported materials from which the soils have formed.

\subsubsection{Soil Classification}

Table 8 presents a summary of the classification of the studied pedons. Soil morphological and laboratory analytical data used to define diagnostic horizons and classifying the soils. Referring the Keys to Soil Taxonomy [18], Pedons KISA-P1 and MKU- P1 were classified as Inceptisols with Greatgroup Endoaquepts correlating to Cambisols of WRB [24]. The soils are less developed with A horizon resting on $\mathrm{C}$ material with shallow water table in most time of the year forming Mollic epipedon and Cambic subsurface horizon. Pedon MBA-P1 was classified as Entisols of Great group Fluvaquents corresponding to a very low developed Fluvisols 
with water saturation during most of the time in the year. In general, these pedons are related with less developed soils probably due to annual floods bringing the new materials. The findings are close to those of [42] who reported 23 Inceptisols and 8 Entisols out of 42 map units mapped in Kilombero Valley. The Entisols and Inceptisols are mostly reported to be used for rice production. In the Philippines,
Inceptisols and Entisols form respectively 13.7 and 2.5\% of the country's soil and are used mainly for rice production [43]. The results indicate that the Entisols and Inceptisols developed under similar conditions to those reported above (aquic SMR and isohyperthemic STR) can be used for rice production.

Table 8. Classification of the studied soil pedons of Kilombero District, Tanzania.

\begin{tabular}{|c|c|c|c|c|c|c|c|c|}
\hline \multirow{2}{*}{$\begin{array}{l}\text { Diagnostic } \\
\text { horizons }\end{array}$} & \multirow{2}{*}{$\begin{array}{l}\text { Other diagnostic } \\
\text { features }\end{array}$} & \multicolumn{4}{|c|}{ KEYS TO SOIL TAXONOMY [24] } & \multicolumn{3}{|c|}{ WRB FOR SOIL RESOURCES [25] } \\
\hline & & Order & Suborder & Great group & Subgroup & Family & $\begin{array}{l}\text { Reference Soil } \\
\text { Group (Tier-1) }\end{array}$ & $\begin{array}{l}\text { WRB soil } \\
\text { name (Tier-2) }\end{array}$ \\
\hline \multicolumn{9}{|l|}{ KISA-P1 } \\
\hline $\begin{array}{l}\text { Mollic } \\
\text { epipedon; } \\
\text { cambic } \\
\text { horizon }\end{array}$ & $\begin{array}{l}\text { Flat, very deep, loamy } \\
\text { over clayey, slightly to } \\
\text { medium acid, aquic } \\
\text { SMR - redoximorphic, } \\
\text { stratification, } \\
\text { Isohyperthermic } \\
\text { STR }\end{array}$ & Inceptisols & Aquepts & Endoaquepts & $\begin{array}{l}\text { Humic } \\
\text { Endoaquepts }\end{array}$ & $\begin{array}{l}\text { Flat, very deep, } \\
\text { loamy over clayey, } \\
\text { slightly to medium } \\
\text { acid, aquic, } \\
\text { isohyperthermic, } \\
\text { Humic } \\
\text { Endoaquepts }\end{array}$ & Cambisols & $\begin{array}{l}\text { Gleyic } \\
\text { Cambisols } \\
\text { (Loamic) }\end{array}$ \\
\hline MKU-P1 & & & & & & & & \\
\hline $\begin{array}{l}\text { Mollic } \\
\text { epipedon; } \\
\text { Cambic } \\
\text { horizon }\end{array}$ & $\begin{array}{l}\text { Flat, very deep, clayey, } \\
\text { slightly to medium acid, } \\
\text { aquic SMR - } \\
\text { redoximorphic, } \\
\text { stratification, } \\
\text { isohyperthermic STR }\end{array}$ & Inceptisols & Aquepts & Endoaquepts & $\begin{array}{l}\text { Humic } \\
\text { Endoaquepts }\end{array}$ & $\begin{array}{l}\text { Flat, very deep, } \\
\text { loamy over clayey, } \\
\text { slightly to medium } \\
\text { acid, aquic, } \\
\text { isohyperthermic, } \\
\text { Humic } \\
\text { Endoaquepts }\end{array}$ & Cambisols & $\begin{array}{l}\text { Dystric Gleyic } \\
\text { Cambisols } \\
\text { (Clayic) }\end{array}$ \\
\hline \multicolumn{9}{|l|}{ MBA-P1 } \\
\hline $\begin{array}{l}\text { Ochric } \\
\text { epipedon }\end{array}$ & $\begin{array}{l}\text { Flat, very deep, clayey, } \\
\text { medium to very strongly } \\
\text { acid, aquic SMR - } \\
\text { redoximorphic, } \\
\text { stratification, } \\
\text { isohyperthermic STR }\end{array}$ & Entisols & Aquents & Fluvaquents & $\begin{array}{l}\text { Typic } \\
\text { Fluvaquents }\end{array}$ & $\begin{array}{l}\text { Flat, very deep, } \\
\text { clayey,, medium to } \\
\text { very strongly acid, } \\
\text { aquic, } \\
\text { isohyperthermic, } \\
\text { TypicFluvaquents }\end{array}$ & Fluvisols & $\begin{array}{l}\text { Eutric Gleyic } \\
\text { Fluvisols } \\
\text { (Clayic, Humic) }\end{array}$ \\
\hline
\end{tabular}

KISA-P1 = Kisawasawa profile MKU-P1 = Mkula profile MBA-P1 = Mbasa profile

SMR $=$ Soil Moisture Regime STR $=$ Soil Temperature Regime

\section{Conclusions and Recommendations}

The studied pedons were deep and had somewhat similar morphological characteristics emanating from similar ecological conditions and mode of formation. The pedons developed under Isohyperthemic soil temperature regime and Aquic soil moisture regime. All pedons had low chromas and abundant mottles (redoximorphic features) due to waterlogging conditions. On the basis of $\mathrm{pH}, \mathrm{CEC}, \mathrm{BS}, \mathrm{SOM}$ and $\mathrm{TN}$, the fertility of the studied soils was generally rated only as medium. Although the studied pedons had all features of recent formation, Pedons KISA-P1 and MKU-P1 (Cambisols) appeared to be relatively more developed than Pedon MBA-P1 (Fluvisol). The soils had optimal nutrient ratios except for $\mathrm{Mg} / \mathrm{K}$ ratios which indicated that plant uptake of $\mathrm{K}$ might be slightly impaired. Based on landform features and soil physico-chemical properties, the soils represented by the three studied profiles were recommended for paddy rice production. Care should be taken though to address possible deficiency of some nutrient elements through judicious use of fertilizers e.g. urea and NPK formulations.

\section{References}

[1] Brady, N. C. and Weil, R. R. (2008). The Nature and Properties of Soils, 12th edition. Prentice-Hall, Inc., Upper Saddle River, NJ, USA. 881 p.

[2] Msanya, B. M., Munishi, J. A., Amuri, N., Semu, E., Mhoro, L and Malley, Z. (2016). Morphology, Genesis, Physicochemical Properties, Classification and Potential of Soils, Derived from Volcanic Parent Materials in Selected Districts of Mbeya Region, Tanzania. International Journal of Plant Soil Science 10 (4): 1-19.

[3] Jatzold, R. and Baum, E. (1968). The Kilombero Valley, Characteristic Features of Economic Geography of a Semihumid East African Floodplain and Its Margins. WeltforumVerlag, Munchen, Dillingen.

[4] Kato, F. (2007). Development of major rice cultivation area in the Kilombero Valley, Tanzania. African Study Monograph 36: 3-18.

[5] Sabugo, R. T. (2013). Adaptation strategies by smallholder rice farmers under the influence of climate change: A case of Kilombero basin, Tanzania. Dissertation for Master of Art in Rural Development Degree at SUA, Morogoro, Tanzania. 97 pp. 
[6] Gharibu F. N. (2014). Effectiveness of Minjingu Mazao as a Source of Phosphorus, Zinc and Copper in Rice Production in Kilombero District- Morogoro, Tanzania. Dissertation for MSc. Soil Science and Land Management of Sokoine University of Agriculture Morogoro, Tanzania. $87 \mathrm{pp}$.

[7] Kilima, F. T. M. (2011). Scaling up Minjingu Phosphate Utilization for Balanced Fertilization of Crops in Tanzania. Participatory socio-economic and agronomic baseline survey Report. Sokoine University of Agriculture, Morogoro, $51 \mathrm{pp}$.

[8] Massawe, B. H. J. and Amuri, N. (2012). Soil Fertility and Agronomic Practices Evaluation for Improved Rice Production in Lowland rice Producing areas Kilombero and Wami Valleys. A Report for ACDI/VOCA Project. Morogoro, Tanzania. 255pp.

[9] Kalala, A. M., Amuri, N. A. and Semoka J. M. R. (2016). Sulphur and Zinc Fertilization Effects on Growth and Yield Response of Rice. International Journal of Plant Soil Science 11 (5): 1-12.

[10] Msanya, B. M., Kaaya, A. K, Araki, S., Otsuka, H. and Nyadzi, G. I. (2003). Pedological characteristics, general fertility and classification of some benchmark soils of Morogoro District, Tanzania. Tanzania. African Journal of Science and Technology (AJST) Science and Engineering Series 4 (2): 101-112.

[11] National Soil Service (1990). Laboratory procedures for routine analysis. $3^{\text {rd }}$ edition. Agricultural Research Institute, Mlingano, Tanga, Tanzania. $212 \mathrm{pp}$.

[12] Ministry of Agriculture Food Security and Cooperatives, Tanzania (MAFSC) (2008). Agricultural maps. Mlingano Agricultural Research Institute. www.kilimo.go.tz/agricultural maps/Tanzania Soil Maps/Soil maps. Site accessed April 2016.

[13] De Pauw (1984). Soils, Physiographic and Agro-ecological Zones of Tanzania. Crop Monitoring and early warning systems project GCS/URT/047. NET. Ministry of Agricultural, Dar Es Salaam. Food and Agriculture organization of the United Nations.

[14] FAO (2006). Guidelines for soil description. 4th edition. Food and Agriculture Organization of the United Nations. Rome, 66 pp.

[15] Munsell Colour Company. (1940). Revised edition. Munsell soil colour charts. Macbeth Division of Kollmorgen Instruments Corporation, New York.

[16] Blake, G. R. and Hartge, K. H. (1986). Bulk density. In: Methods of soil analysis, Part 1 Physical and mineralogical methods. (Edited by Klute A.). American Society of Agronomy. Madison, Wisconsin. Pp 364-374.

[17] Day, P. R. (1965). Particle fractionation and particle size analysis. In: Black, C. A., Evans, D. D, White, J. L., Ensminger, L. E. and Clark F. E. (Eds.). Methods of soil analysis: Physical and mineralogical methods, American Society of Agronomy, Madison, Wisconsin. Pp 545-566.

[18] Soil Survey Staff. (2014). Keys to Soil Taxonomy. 12th Edition. United States Department of Agriculture, Natural Resources Conservation Service.

[19] Okalebo, J., R., Gathua, K. W. and Woomer, P. L. (2002). Laboratory Methods Of Soil and Plant Analysis: 2nd Edition.
A working manual. 128pp.

[20] Nelson, D. W. and Sommers, L. E. (1982). Total carbon, organic carbon and organic matter. In: Methods of soil analysis, Part 2; Chemical and mineralogical properties, 2nd edition. (Edited by Page, A. L., Miller, R. H. and Keeney, D. R.). American Society of Agronomy., Madison, Wisconsin. Pp 539-557.

[21] Bremner, J. M. and Mulvaney, C. S. (1982). Total nitrogen. In: Methods of Soil Analysis. Part 2. Agronomy Monograph 9, American Society of Agronomy, Madison, Wisconsin, USA. pp $1149-1170$.

[22] Thomas, G. W. (1996). Exchangeable cations. In: Methods of Soil Analysis. American Society ofAgronomy\& Soil Science Society of America, Madison, Wisconsin.

[23] Chapman, H. D. (1965). Cation exchange capacity. In: Methods of Soil Analysis. Edited by Black CA. American Institute of Agronomy 9: 891-901.

[24] IUSS Working Group WRB (2014). World Reference Base for Soil Resources 2014 updates. International Soil Classification System for Naming Soils and Creating Legends for Soil Maps. World Soil Resource Report No. 106. FAO, Rome.

[25] Akpan-Idiok, A. U. and Ogbaji, P. O. (2013). Characterization and Classification of Onwu River Floodplain Soils in Cross River State, Nigeria. International Journal of Agricultural Research 8: 107-122.

[26] Obasi, S. N., Onweremadu, E. U., Egbuche, C. T. and Iwuanyanwu, U. P. (2015). Characterization and Classification of Selected Rice Soils of Tropical Rainforest Region, Southeastern Nigeria. Agriculture, Forestry and Fisheries 4 (3): 4650 .

[27] Khan, Z. H., Hussain, M. S. and Ottner, F. (2012). Morphogenesis of Three Surface-Water Gley Soils from the Meghna Floodplain of Bangladesh. Dhaka University Journal of Biological Science 21 (2): 17-27.

[28] Kebeney, S. J., Msanya, B. M., Ng'etich, W. K, Semoka, J. M. R. and Serrem. C. K. (2015). Pedological Characterization of Some Typical Soils of Busia County, Western Kenya: Soil Morphology, Physico-Chemical Properties, Classification and Fertility Trends. International Journal of Plant Soil Science 4 (1): 29-44.

[29] Uwingabire, S., Msanya, B. M., Mtakwa, P. W., Uwitonze, P. and Sirikare, S. (2016). Pedological Characterization of Soils Developed on Gneissic- Granites in the Congo Nile Watershed Divide and Central Plateau Zones, Rwanda. International Journal of Current Research 8 (09): 39489-39501.

[30] Uwitonze, P., Msanya B. M., Mtakwa, P. W., Uwingabire, S. and Sirikare, S. (2016). Pedological Characterization of Soils Developed from Volcanic Parent Materials of Northern Province of Rwanda. Agriculture, Forestry and Fisheries 5 (6): 225-236.

[31] Landon, J. R. (1991). Booker Tropical Soil Manual: A handbook for soil survey and agricultural land evaluation in the tropics and subtropics. John Wiley and Sons: New York $450 \mathrm{p}$.

[32] USDA-NRCS (2016). Soil bulk density/moisture/aeration. Soil quality kit-Education for educators. Accessed October October, 2016. 
[33] Lal, R. and Shukla, M. K. (2005). Principles of soil physics. Marcel Dekker, Inc. New York. Basel. 699pp.

[34] Massawe, B. H. J. (2015). Digital Soil Mapping and GISbased Land Evaluation for Rice Suitability in Kilombero Valley, Tanzania. PhD thesis. Graduate School of Ohio State University.

[35] EUROCONSULT. (1989). Agriculture Compendium for Rural Development in the Tropics and Sub-Tropics. 3rd Revised edition. Elsevier, Amsterdam. Oxford. New York. Tokyo. 740pp.

[36] Msanya, B. M., Kimaro, D. N., Kimbi, G. G. and Munisi, A. L. M. (2001). Land resources inventory and suitability assessment for the production of the major crops in the eastern part of Morogoro Rural District, Tanzania. Department of Soil Science, 3: 1 - 69 .

[37] Magoggo, J. P., Msanya, B. M. and Kimaro, D. N. (1996). Environmental profile for agricultural production and development of conservation strategies in Mahenge Village, Mbinga District, Tanzania. Miombo Woodland Research Project, Natural Resources Study Team Technical Report 3. Department of Soil Science, Sokoine University of Agriculture, P. O. Box 3008, Morogoro, Tanzania \& Ministry of Agriculture, National Soil Service, ARI Mlingano, Tanga, Tanzania. 38p.
[38] Msanya, B. M., Kimaro, D. N. and Magoggo, J. P. (1995). Characteristics of two pedons and their implication for environmental management in parts of Mbinga District, Tanzania. Paper presented at the first annual Faculty of Agriculture Research Conference. August 28-30th. Sokoine University of Agriculture, Morogoro, Tanzania.

[39] Meliyo, J. L. (1997). Pedological investigation and characterization in Litembo village, Mbinga District, Tanzania. MSc (Agric). Dissertation, Sokoine University of Agriculture, Morogoro, Tanzania. 113p.

[40] Baba, M., Hennie, F. W., Soehady, E. and Sanudin, T. (2008). Geochemical characterization of volcanic soils from Tawau, abah. Geological Society of Malaysia Bulletin, 54: 33-36.

[41] Nesbitt, H. W and Young, G. M. (1982). Early Proterozoic climates and plate motions inferred from major element chemistry of Lutites. Nature 299: 715-717.

[42] FAO. (1961). The Rufiji Basin, Tanganyika. FAO Experts Technical. Assistance Programme. No. 1269, Vol. 7. Rome.

[43] FAO. (2006). Country Pasture/Forage Resource Profiles. Philippines.

http://www.fao.org/ag/aGp/agpc/doc/Counprof.Philippines.pdf. Accessed December 2016. 